\author{
Antoni Frodyma \\ Instytut Nafty i Gazu - Państwowy Instytut Badawczy \\ Piotr Koślik \\ Instytut Przemysłu Organicznego
}

\title{
Analiza numeryczna ładunków kumulacyjnych do inicjowania propelantów modyfikowanych
}

\begin{abstract}
W artykule przedstawiono wyniki modelowania numerycznego procesu detonacji trzech ładunków kierunkowych, w różnych trybach pracy: hybrydowym, hybrydowym z przesłoną, hiperkumulacyjnym, przeprowadzonego w celu sprawdzenia, czy energia dostarczana przez strumień kumulacyjny może pewnie pobudzać zapłon paliwa stałego (propelantu) w układzie pracy kompleksowego urządzenia perforująco-szczelinującego. Oszacowanie energii z symulacji numerycznych porównano $\mathrm{z}$ energiami uzyskanymi w eksperymentach strzałowych poligonowych przeprowadzonych wcześniej na rzeczywistych układach perfogeneratora, uzyskując potwierdzenie możliwości inicjowania paliwa stałego strumieniem kumulacyjnym pochodzącym ze wszystkich trzech wersji ładunku kierunkowego.
\end{abstract}

Słowa kluczowe: ładunki kierunkowe, symulacja numeryczna, inicjowanie propelantów.

\section{Numerical analysis of shaped charges for igniting modified propellants}

The article presents results of numerical modeling of a detonation process for three shaped charges in various operation modes: the hybrid one, the hybrid with a diaphragm and hypercumulation, performed in order to verify whether the energy delivered by a cumulative stream can surely ignite a propellant within the working arrangement of a complex perforating - fracturing device. Estimation of the energy obtained by numerical method was compared with energies obtained earlier in fire ground experiments with real perforating - fracturing device models, giving confirmation of the possibility of propellant ignition with a cumulative jet derived from all three versions of the considered shaped charges.

Key words: perfogenerator shaped charges, numerical simulation, initiation of propellants, combined perforator-generator.

\section{Wprowadzenie}

Autorzy postawili sobie za cel sprawdzenie, $\mathrm{z}$ wykorzystaniem symulacji numerycznych, cech nowych ładunków kierunkowych, które pozwolą na skuteczne wykorzystanie ich w urządzeniu perforująco-szczelinującym (perfogeneratorze). Artykuł przedstawia przegląd wiadomości z zakresu nowych ładunków kierunkowych i paliw stałych (propelantów) współcześnie stosowanych $\mathrm{w}$ pracach intensyfikacyjnych w górnictwie naftowym oraz symulację numeryczną spalania trzech róż- nych wersji ładunków kierunkowych nowego typu, ze szczególnym uwzględnieniem nowych koncepcji ładunków hybrydowych/hiperkumulacyjnych i możliwości zapalania przez nich wybranych paliw stałych/wysokoenergetycznych. Wybrane modele symulowanych układów odpowiadają poszukiwanym nowym rozwiązaniom możliwym do przemysłowego zastosowania w nieodległej przyszłości w pracach dotyczących intensyfikacji przypływu do odwiertu (bądź poprawy chłonności).

\section{Zjawisko kumulacji, ładunki kierunkowe (kumulacyjne)}

Klasyczny efekt kumulacyjny opiera się w swym założeniu na miejscowym zintensyfikowaniu działania detonacji.
Nasilone działanie uzyskuje się w układach wybuchowych podłużnych, najczęściej osiowosymetrycznych, w których na 
jednym z końców znajduje się wgłębienie zwane wydrążeniem kumulacyjnym. W przypadku pobudzenia do detonacji takiego ładunku z naprzeciwległego końca względem wydrążenia to działanie w kierunku osi wgłębienia będzie znacznie intensywniejsze niż w układach wybuchowych płaskich bez wydrążenia kumulacyjnego. Kolejnym rozwinięciem układu potęgującego efekt kumulacji jest pokrycie wydrążenia wkładką kumulacyjną (najczęściej miedzianą). Działanie to wielokrotnie zwiększa zdolność przebicia przeszkody przez strumień kumulacyjny [11].

Ładunki kumulacyjne są szeroko wykorzystywane zarówno w zastosowaniach militarnych [8], jak również w cywilnych, między innymi w inżynierii materiałowej (np. cięcie wybuchowe) czy też górnictwie (perforacja w otworach ropnych i gazowych) [12].

Badania zjawiska kumulacji energii materiału wybuchowego (krótko: zjawiska kumulacji) można rozpocząć od rozpatrzenia działania ładunku wydrążonego bez wkładki kumulacyjnej. Przy zastosowaniu ładunków zwykłych, tj. bez wydrążenia, mamy do czynienia z kulistym rozchodzeniem się produktów wybuchu i fal uderzeniowych. Na skutek takiego ruchu rozchodzenia się następuje szybki spadek parametrów gazu (ciśnienia, prędkości, gęstości), wywołany rozkładem energii wybuchu na wciąż rosnącą objętość kuli, związaną z ruchem produktów detonacji. Na odwrót, przy schodzeniu się produktów detonacji lub fal uderzeniowych, dochodzi do wzrostu parametrów gazu w rozpatrywanym ośrodku. Efektem ruchu schodzenia się jest gwałtowne zwiększenie się energii gazu, co prowadzi do znacznego nasilenia niszczącego działania wybuchu [11].

Działanie kumulacyjne jest związane z dużym zagęszczeniem energii zawartej w produktach detonacji oraz $\mathrm{w}$ falach uderzeniowych powstających przy wybuchu. W zjawisku kumulacji, gdy schodzą się kuliście fale uderzeniowe lub detonacyjne, w miejscu ich spotkania może powstawać ciśnienie rzędu milionów atmosfer. Taki rodzaj kumulacji można osiągnąć, stosując ładunek w kształcie kuli wydrążonej, pobudzony jednocześnie na całej powierzchni zewnętrznej. Z takim rodzajem czysto promieniowej kumulacji w praktyce spotykamy się rzadko [11].

Najważniejsze znaczenie praktyczne ma kumulacja ukierunkowana osiowo, którą można uzyskać podczas wybuchu ładunków cylindrycznych o wydrążeniu w kształcie zbliżonym do stożka, półkuli, paraboloidy, hiperboloidy, elipsoidy lub powstałym z połączenia tych powierzchni [11].

Stożkowa wkładka kumulacyjna (klasyczna) w trakcie detonacji ładunku jest zgniatana symetrycznie i z jej wewnętrznych warstw generowany jest strumień kumulacyjny o średnicy do około $10 \mathrm{~mm}$, którego czoło porusza się z prędkością dochodzącą do $8 \div 10 \mathrm{~km} / \mathrm{s}$, podczas gdy zgnieciona wkładka (tzw. zbitka kumulacyjna) podąża w tym samym kierunku z prędkością około $1 \mathrm{~km} / \mathrm{s}$. Ze względu na monotoniczny spadek prędkości elementów strumienia poczynając od jego czoła, strumień kumulacyjny ulega wydłużaniu w trakcie swobodnego lotu, aż do przerwania ciągłości i rozpadu na drobne fragmenty, które nie mają zdolności do penetracji twardych przegród $[1,2]$.

\section{Zagadnienie hiperkumulacji}

Zagadnienia związane z hiperkumulacją stanowią rozwinięcie klasycznej teorii kumulacji. Przedstawiają stosunkowo nowe spojrzenie na kwestię ukierunkowania i koncentracji energii wybuchu. Procesy związane z hiperkumulacją, do niedawna zaniedbane i zapomniane, znajdują na nowo zainteresowanie w środowisku naukowym badającym fizykę wybuchu.

W artykule zawarto skrócony zarys teorii powstawania strumieni hiperkumulacyjnych. Fizyka powstawania tzw. hiperkumulacji jest przedstawiona w szczegółach przy użyciu narzędzi numerycznych przez symulacje komputerowe. Wykazano, że efekt hiperkumulacji pozwala zwiększyć zarówno prędkość, jak i masę skumulowanych strumieni znacznie bardziej niż teoria klasyczna, opisana między innymi przez Lavrentyev i Birkhoffa. Istnieje możliwość zastosowania nowych rozwiązań do opracowania ładunków hybrydowych $\mathrm{z}$ efektem hiperkumulacji [10].
Jak przedstawiono w patentach i pracach Minina [10, 13-15], w modelach, gdzie kąt zapadania (kolizji) przekracza $180^{\circ}$, układy takie charakteryzują się pojawieniem się nowej klasy strumieni: masa strug kumulacyjnych staje się większa niż masa zbitki (do niemal całkowitego zaniku zbitki). Przy zderzaniu strumienia o kącie większym niż $180^{\circ}$, strumień i zbitek mają tendencję do zamiany miejscami. Prędkość masywnych strug jest znacznie większa, podczas gdy prędkość zbitki znajduje się na bardzo niskim poziomie. Bezpośrednie utworzenie ładunków z ostrą wkładką, które wykorzystują przepływ materiałów taki jak przy kolizji o kącie większym niż $180^{\circ}$, jest niemożliwe w klasycznych układach kumulacyjnych. Zespół pod kierunkiem profesora Minina zaproponował stosowanie płaskich bądź kształtowych przesłon (krążków) umieszczanych w osi symetrii na wkładkach stożkowych. Układ taki pozwala uzyskać kąt tworzenia strumienia przekraczający $180^{\circ}$. 


\section{Paliwa wysokoenergetyczne (propelanty)}

Stałe paliwa prochowe, występujące jako element tworzenia operatora oddziaływania gazodynamicznego w perfogeneratorach, stanowiących połączenie $\mathrm{w}$ jednym urządzeniu perforatora i generatora prochowego (np. w formie płaszcza rurowego otaczającego korpus perforatora), można podzielić na jednorodne (homogeniczne) i złożone (kompozycyjne). Z kolei paliwa homogeniczne mogą być dalej klasyfikowane jako jedno- lub dwubazowe. Paliwa monobazowe składają się z jednego zasadniczego składnika, którym jest na ogół nitrocelulo- za, posiadająca zarówno własności utleniające, jak i redukcyjne. Paliwa dwubazowe zbudowane są zwykle z mieszaniny nitrocelulozy i nitrogliceryny, zazwyczaj z dodatkiem plastyfikatorów. Nowoczesne paliwa kompozycyjne (złożone) stosowane $\mathrm{w}$ górnictwie naftowym to mieszanina prochów zawierająca skrystalizowane bądź rozdrobnione sole nieorganiczne pełniące rolę utleniacza oraz chloran(VII) amonu, stanowiący $60 \div 90 \%$ masy całego paliwa. Produkt końcowy ma konsystencję przypominającą twardą szkolną gumkę do mazania [3].

\section{Inicjacja spalania paliwa}

Proces inicjowania zapłonu paliwa, stanowiący oś zagadnień omawianych w tym artykule, polega na doprowadzeniu odpowiedniej ilości ciepła, które zapoczątkuje reakcję egzotermiczną i wzrost temperatury ziaren paliwa. Reakcja postępuje, rozprzestrzenia się i dociera do innych części materiału nieobjętego początkowo reakcją. Reakcja rozprzestrzeniania ciepła może postępować nawet wtedy, gdy jego źródło zostanie odłączone. Ilość ciepła konieczna do zapoczątkowania reakcji egzotermicznej i zapłonu paliwa nosi nazwę energii inicjacji [7].

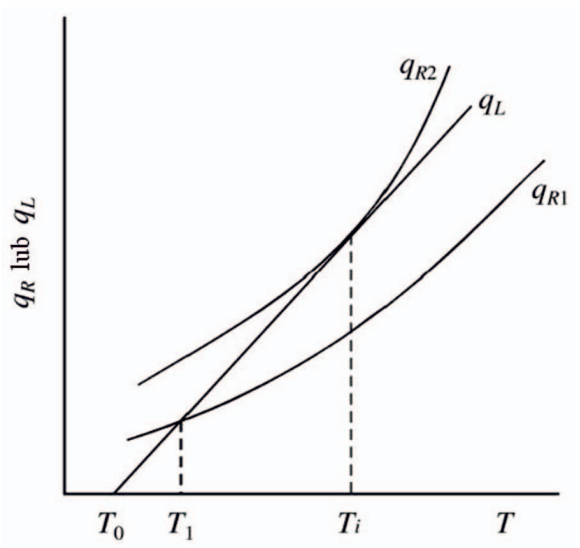

Rys. 1. Kryterium inicjacji paliwa w reżimie straty i zysku ciepła

Proces inicjacji paliwa wysokoenergetycznego można zobrazować w sposób następujący: gdy została zainicjowana reakcja egzotermiczna, to tempo wytwarzania ciepła przez materiał reakcyjny jest przedstawione krzywą wykładniczą $q_{R}$. Układ straci część ciepła $q_{L}$, proporcjonalną do różnicy temperatur w zbiorniku i otoczeniu. Krzywe $q_{R}$ i $q_{L}$ przedstawione sa $\mathrm{w}$ formie graficznej na rysunku $1 \mathrm{w}$ funkcji temperatury: $T_{i}$ odpowiada temperaturze zapłonu gazu reakcyjnego. Zakładając, że krzywa $q_{R 1}$ przedstawia tempo generowania ciepła, samopodtrzymujące się ogrzewanie nastąpi w $T_{0}$ bez straty ciepła, a temperatura wzrośnie do wartości $T_{1}$. Gdy temperatura osiągnie $T_{1}$, strata ciepła $q_{L}$ będzie odpowiadała $q_{R 1}$, a dalszy wzrost temperatury jako skutek postępującej reakcji egzotermicznej zostanie przerwany wraz z osiągnięciem temperatury $T_{1}$. Dlatego temperatura układu nigdy nie osiągnie temperatury zapłonu $T_{i}$. W innym przypadku, gdy rozważymy przebieg krzywej $q_{R 2}$, również reprezentującej wzrost wydzielanego ciepła reakcji, samopodtrzymujące się ogrzewanie spowoduje wzrost temperatury do $T_{i}$, ponieważ $q_{R 2}>q_{L}$ W zakresie temperatur $T_{0}$ i $T_{i}$. W przedziale temperatur powyżej $T_{i}: q_{R 2}>q_{L}$, Zwiększenie ilości wydzielanego ciepła postępuje, zapewniając zapłon.

Z punktu widzenia zagadnień postawionych do zbadania w niniejszej pracy istotne jest sprawdzenie, czy wielkość energii generowanej przez strumień kumulacyjny ładunku kierunkowego w punkcie jego zderzania się z płaszczem paliwa wysokoenergetycznego, osadzonego na korpusie perforatora uzbrojonego ładunkami kierunkowymi, jest wystarczająca do wywołania zapłonu paliwa wysokoenergetycznego.

\section{Analizy numeryczne układów kumulacyjnych hybrydowych i hiperkumulacyjnych}

Analizy procesu formowania strumieni kumulacyjnych przeprowadzono przy zastosowaniu modelowania komputerowego w programie ANSYS Autodyn.

Wykorzystując algorytmy Eulera, wszystkie modele oparto na siatce elementów skończonych, na której budowano geometrię poszczególnych układów. Domena Eulerowska dla bardzo szybkich procesów, takich jak propagacja wybuchu, kolizja strumieni, fragmentacja obudów itp., w których występują bardzo duże odkształcenia, jest stabilniejszym układem obliczeniowym w odniesieniu do algorytmów Lagrange'a. W przypadku tego typu opisu model dyskretny przemieszcza się na tle siatki elementów skończonych. 
Do opisu matematycznego zjawisk zachodzących w czasie wybuchu i propagacji fali uderzeniowej, deformacji i napędzania wkładek zastosowano równania stanu opisujące fizyczne procesy przemiany zwane EOS [5].

\section{Modele układów kumulacyjnych}

W dalszej części pracy przedstawione zostały analizy trzech różnych układów kumulacyjnych, zaczynając od kumulacji w modelu wkładki hybrydowej, poprzez dodanie do niego przesłony, a następnie zastosowanie modelu hiperkumulacji. Modele geometryczne budowano w układzie osiowosymetrycznym w postaci dwuwymiarowej (2D). Symulacje komputerowe wykonano z użyciem programu ANSYS Autodyn.

Wyniki modelowania przedstawiono według poniższej kolejności:

- MODEL ŁKH45-140-40-Mg; ładunek kumulacyjny hybrydowy - wkładka kumulacyjna $140 \mathrm{Cu} 2 \mathrm{~mm}+40 \mathrm{Cu}$;

- MODEL ŁKH45-140-40-Cu-przesłona; ładunek kumulacyjny hybrydowy z przesłoną - wkładka kumulacyjna $140 \mathrm{Cu} 2 \mathrm{~mm}+40 \mathrm{Cu}$;

- MODEL ŁK45-HIPERKUM-50-Mg; ładunek z efektem hiperkumulacji, wkładka magnezowa $50^{\circ}$.

\section{MODEL ŁKH45-140-40-Mg; ładunek kumulacyjny} hybrydowy - wkładka kumulacyjna 140Cu2mm + 40Cu

Do pierwszego (I) cyklu analiz numerycznych wybrano konstrukcję małokalibrowego ładunku kumulacyjnego o średnicy wkładki $45 \mathrm{~mm}$ i konstrukcji hybrydowej, tj. o podwójnym kącie wierzchołkowym wkładki: $140^{\circ}$ i $40^{\circ}$. Wkładkę kumulacyjną centralną z miedzi o kącie wierzchołkowym $40^{\circ}$ przyjęto o zmiennej grubości: od $0,5 \mathrm{~mm}$ w czę- ści wierzchołkowej do $2 \mathrm{~mm}$ u podstawy. Część zewnętrzna wkładki, także z miedzi, o kącie wierzchołkowym $140^{\circ}$, posiada grubość $2 \mathrm{~mm}$.

Charakterystyczne cechy geometryczne układu hybrydowego ładunku z wkładką o przyjętej konstrukcji wraz z siatką współrzędnych przedstawiono na rysunku 2.

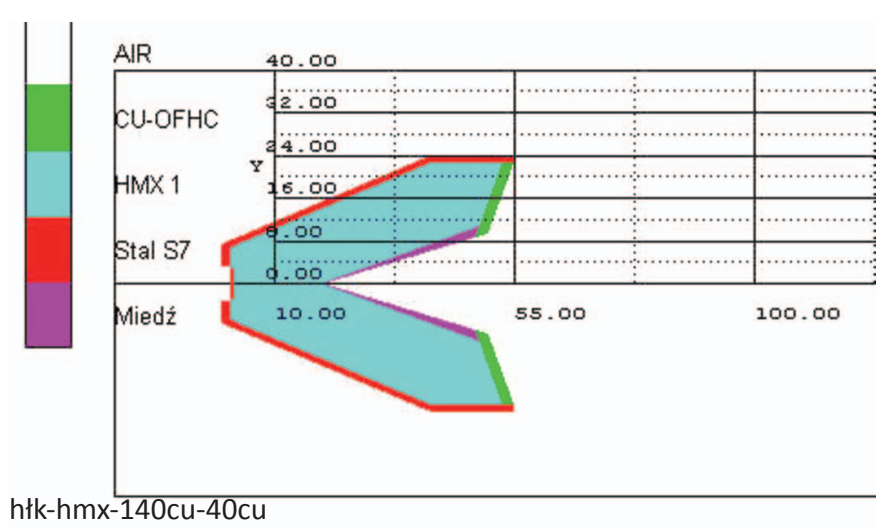

Rys. 2. MODEL ŁKH45-140-40-Cu; ładunek kumulacyjny hybrydowy - wkładka kumulacyjna $140^{\circ} \mathrm{Cu} 2 \mathrm{~mm}+40^{\circ} \mathrm{Cu}$

Model 2D ładunku o symetrii osiowej umieszczony jest w przestrzeni o długości $300 \mathrm{~mm}$ (współrzędna $X$ od -20 mm do $280 \mathrm{~mm}$ ) i szerokości $80 \mathrm{~mm}$ (wspótrzędna promieniowa $Y$ od $0 \mathrm{~mm}$ do $40 \mathrm{~mm}$ ). Współrzędną odległości $\mathrm{X}$ dobrano z podziałem równym kalibrowi wkładki (45 mm). Wówczas zaznaczone na osi X odległości (X = 55 mm, $100 \mathrm{~mm}, 145 \mathrm{~mm}$, $190 \mathrm{~mm}, 235 \mathrm{~mm}$ i $280 \mathrm{~mm}$ ) odpowiadają dystansom od podstawy wkładki kumulacyjnej mierzonym jej krotnością w kalibrach $S=0,1,2,3,4,5$. Miejsce (powierzchnię) inicjowania detonacji ładunku oznaczono w modelu kolorem czerwonym: $\mathrm{X}=2 \mathrm{~mm}, \mathrm{Y}=\mathrm{od}-3 \mathrm{~mm}$ do $3 \mathrm{~mm}$. Przyjęto $\mathrm{w}$ tym

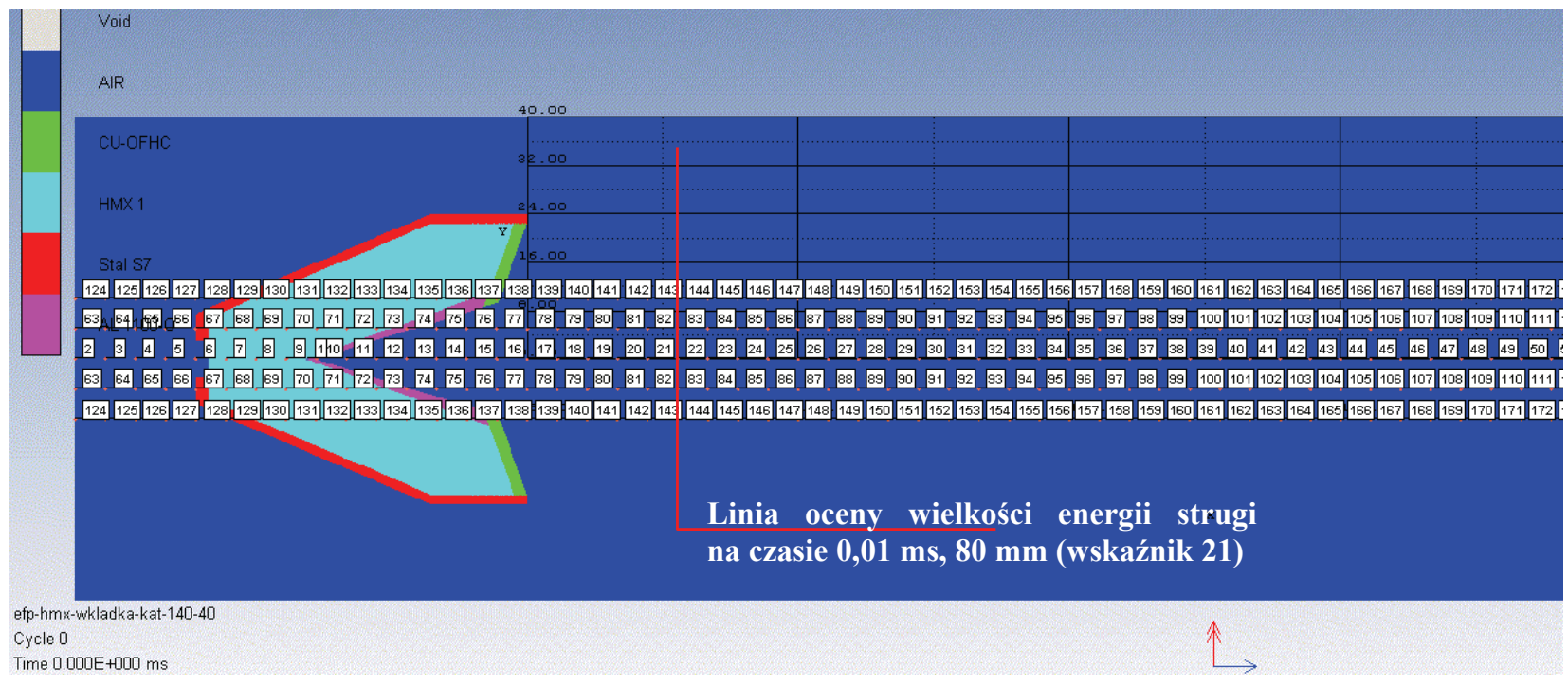

Rys. 3. MODEL ŁKH45-140-40-Al; oznaczenie i rozmieszczenie punktów kontrolnych z zaznaczeniem przybliżonego położenia linii oceny energii kinetycznej strugi (80 mm od czoła wkładki) 
modelu inicjowanie detonacji powierzchnią, co odpowiada inicjowaniu spłonką o średnicy $6 \mathrm{~mm}$.

Model numeryczny oparto na założeniach Eulera. W modelu przyjęto dane materiałowe $\mathrm{z}$ dostępnej bazy danych programu ANSYS Autodyn - odpowiednio: AIR (przestrzeń powietrza), CU-OFHC (miedź - materiał wkładki kumulacyjnej $140^{\circ}$ ), miedź (miedź - materiał wkładki kumulacyjnej $40^{\circ}$ ), HMX (oktogen - materiał wybuchowy), stal S7 (stal - osłonka ładunku). Stan zachowania się powietrza w analizowanym układzie model opisuje z zastosowaniem równań stanu dla gazów doskonałych. Dla powietrza we wszystkich analizowanych modelach przyjęto ciśnienie normalne. Do opisu procesu detonacji materiału wybuchowego zastosowano równania stanu EOS JWL (równanie Jonesa, Wilkinsa i Lee). Do opisu równania stanu materiału wybuchowego HMX w modelu przyjęto parametry z bazy danych programu ANSYS Autodyn. Na potrzeby analiz różnych parametrów możliwych do uzyskania w cyklu symulacji komputerowych dobrano w modelu szereg punktów kontrolnych. Ich oznaczenie i rozmieszczenie przedstawiono na rysunku 3.

Na rysunku 4 przedstawiono wybrane sekwencje obrazów konturów ciśnień w czasie detonacji MW (materiał wy-
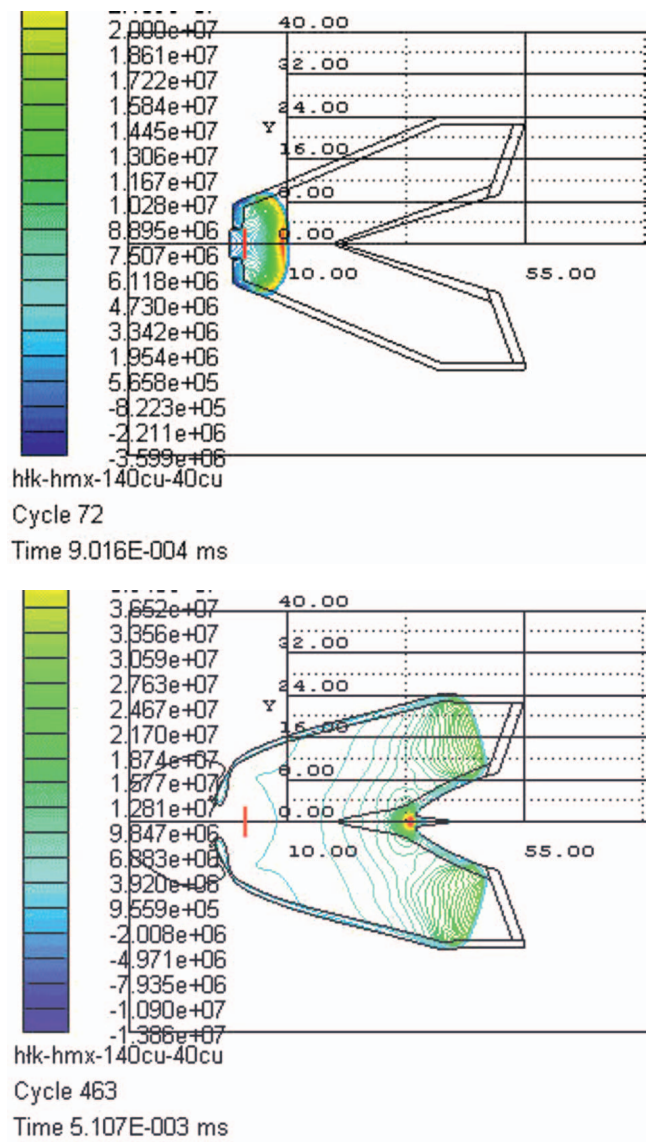

buchowy) w ładunku. Koniec detonacji MW obserwuje się dla czasu około $6 \mu$ s.

Na rysunku 5 przedstawiono wybrane sekwencje obrazów ilustrujących proces obciskania wkładki kumulacyjnej i formowania się strumienia (pocisku).

Na podstawie przedstawionych sekwencji położenia czoła strumienia (pocisku) w określonych odległościach (od $S=0$ do $S=5$ ) można oszacować jego prędkość Vo. Zestawienie danych do analizy prędkości czoła strumienia Vo przedstawiono w tablicy 1.

Tablica 1. Dane do analizy modelu ładunku ŁKH45-140Cu-40Cu (model nr 1)

\begin{tabular}{|c|c|c|c|c|}
\hline Cykl & $\begin{array}{c}\text { Czas } \\
{[\mu \mathrm{s}]}\end{array}$ & $\begin{array}{c}\text { Dystans X } \\
{[\mathrm{mm}]}\end{array}$ & $\begin{array}{c}\text { Dystans } \\
\text { w kalbrach }\end{array}$ & $\begin{array}{c}\text { Vo } \\
{[\mathrm{km} / \mathrm{s}]}\end{array}$ \\
\hline 664 & 7,104 & 55 & $S=0$ & \\
\hline 1281 & 13,210 & 100 & $S=1$ & 7,370 \\
\hline 1813 & 19,210 & 145 & $S=2$ & 7,500 \\
\hline 2341 & 25,210 & 190 & $S=3$ & 7,500 \\
\hline 2943 & 31,300 & 235 & $S=4$ & 7,389 \\
\hline 5178 & 37,200 & 290 & $S=5$ & 7,627 \\
\hline
\end{tabular}
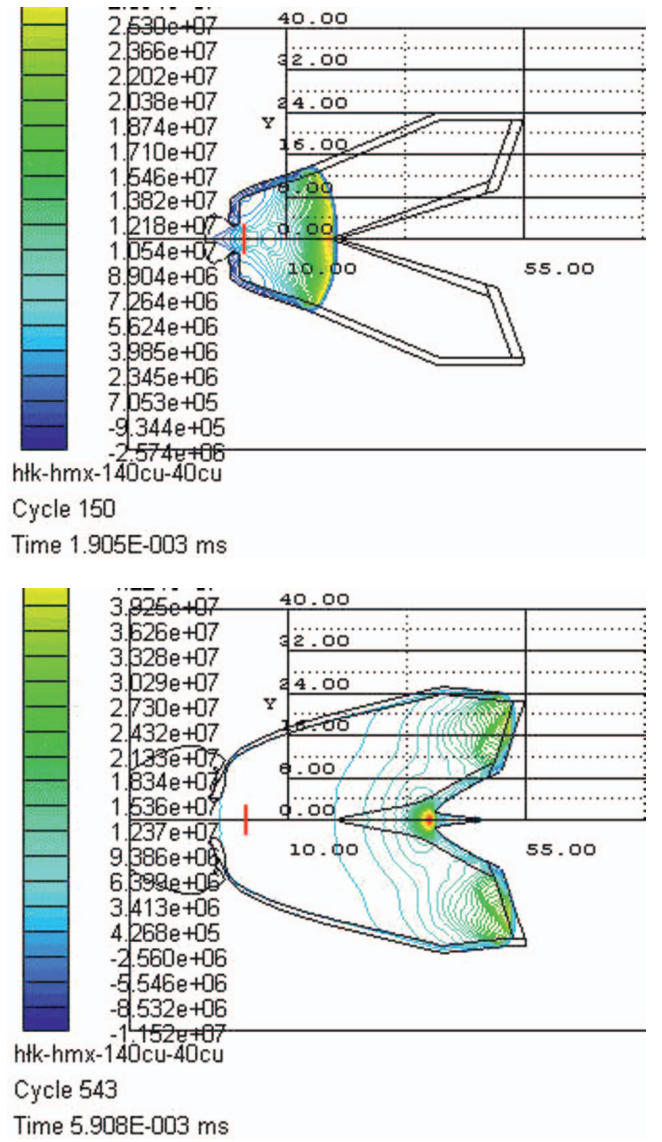

Rys. 4. Faza detonacji MW w ładunku; obrazy konturów ciśnień dla czasów $T=0,9016 \mu \mathrm{s}, T=1,905 \mu \mathrm{s}, T=5,107 \mu \mathrm{s}, T=5,908 \mu \mathrm{s}$ 


\section{NAFTA-GAZ}
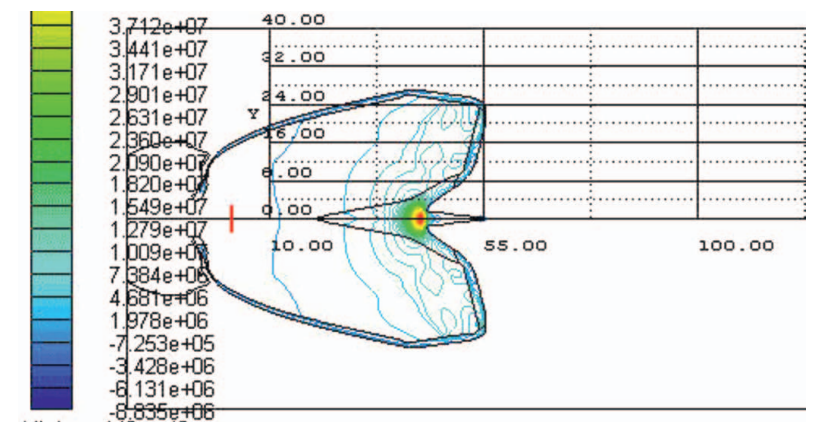

htk-hmx-140cu-400

Cycle 664

Time 7.104E-003 ms

$S=0$

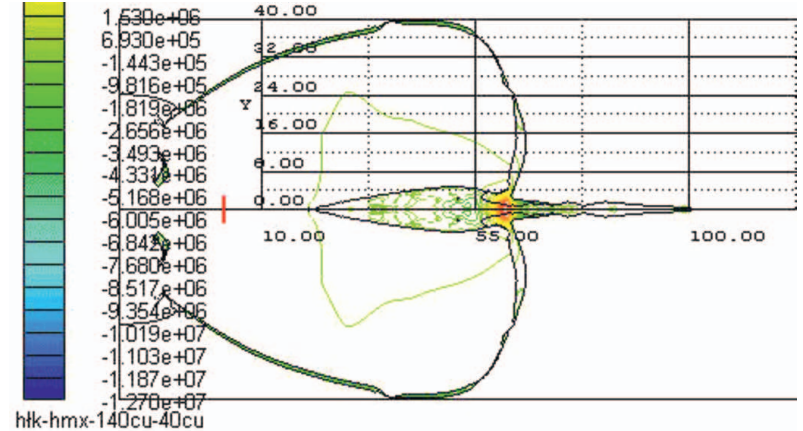

Cycle 1281

Time 1.321E-002 ms

$S=1$

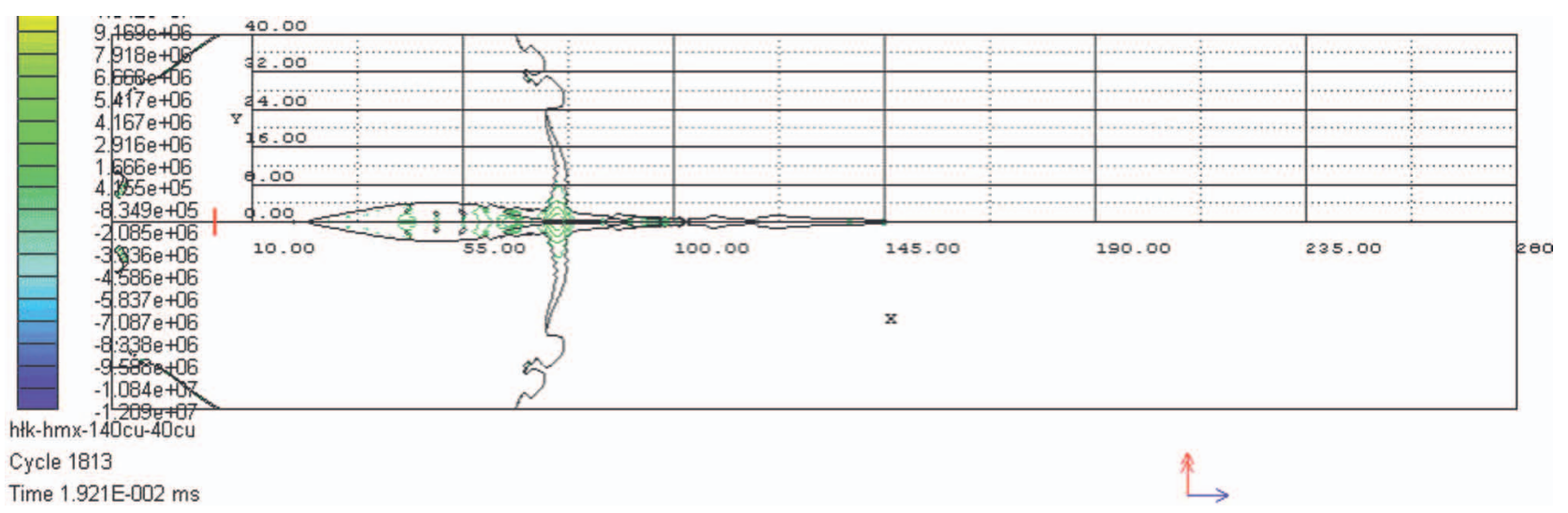

$S=2$

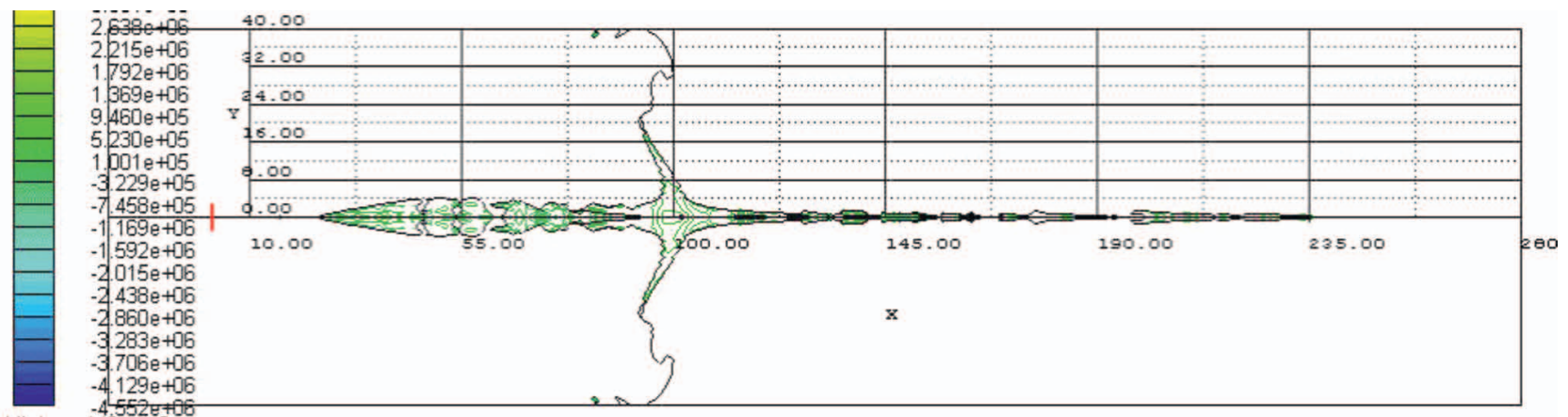

htk-hmx-140 $-145-40 \mathrm{cu}$

Cycle 2943

Time 3.130E-002 ms

$S=4$
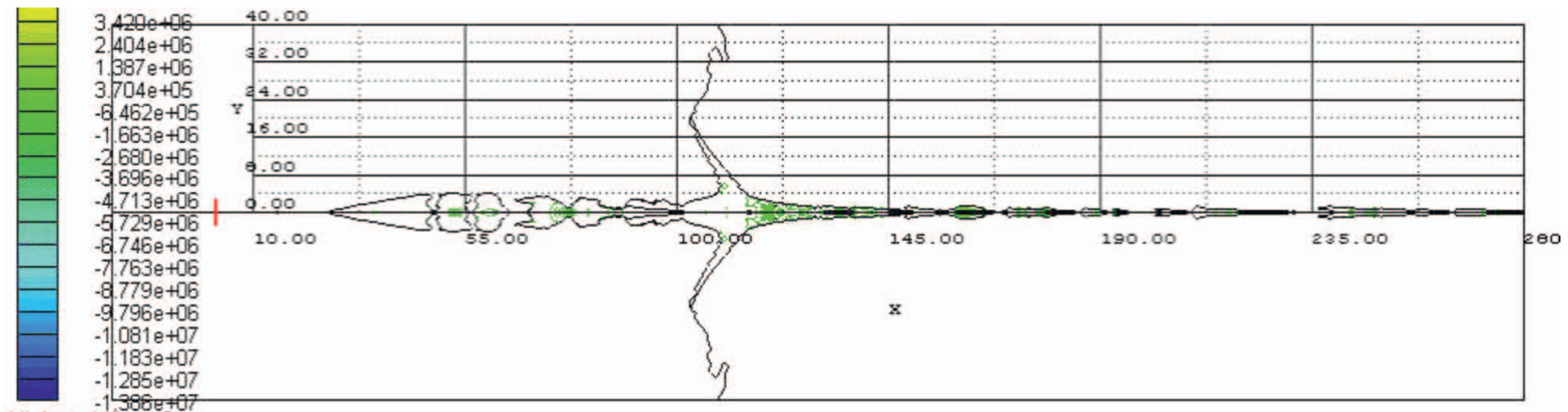

htk-hmx-140 cu-40 cu

Cycle 5178

Time 3.720E-002 ms

$S=5$

Rys. 5. Proces obciskania wkładki kumulacyjnej i formowania strumienia (pocisku); widok na dystansach od czoła: $S=0(T=7,104 \mathrm{~s}), S=1(T=13,21 \mu \mathrm{s}), S=2(T=19,21 \mu \mathrm{s}), S=4(T=31,30 \mu \mathrm{s}), S=5(T=37,20 \mu \mathrm{s})$ 
Material Summary (Ident $\left.0-h^{3} k-h m x-140 c u-40 c u\right)$

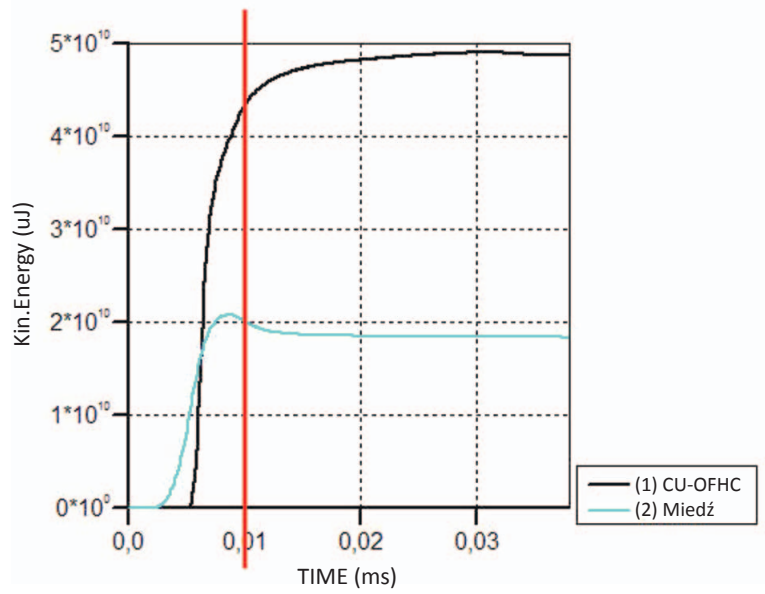

a)

Rys. 6. Przykłady wybranych analiz dla modelu; a) wykresy energii kinetycznej elementów hybrydowej wkładki kumulacyjnej, b) wykres historii prędkości wzdłuż strumienia ( $X$-velocity) dla wybranych punktów kontrolnych odpowiadających odpowiednio położeniom: $S=0$ (pkt 17), $S=1$ (pkt 26), ... S=5 (pkt 61)
Prędkość czoła strumienia powstałego z centralnej wkładki miedzianej - na odcinkach określonych w tablicy 1 na dystansach od $S=0$ do $S=5$ mieści się w granicach $7370 \div 7627 \mathrm{~m} / \mathrm{s}$.

Oszacowana średnia prędkość czoła strumienia kumulacyjnego mierzona dla różnicy położeń od $S=0$ do $S=5$ (tj. na dystansie 5 kalibrów wkładki kumulacyjnej) wynosi: Vośr $=(290-55) \mathrm{mm} /(37,2-7,104) \mu \mathrm{s}=235 \mathrm{~mm} / 30,096$

$$
\mu \mathrm{s}=7,808 \cdot 10^{3} \mathrm{~m} / \mathrm{s}
$$

Średnia prędkość czoła strumienia na małych odległościach od czoła ładunku, mierzona na dystansie pierwszych 5 kalibrów wkładki $(S=5)$, wynosi około 7,81 km/s.

$\mathrm{Na}$ rysunkach $6 \mathrm{a}$ i $6 \mathrm{~b}$ przedstawiono wybrane inne przykłady analizy danych dla modelu, które program gromadzi w procesie całego cyklu symulacji. Punkty, w których oszacowano energię kinetyczną i prędkości strumienia, zaznaczono na wykresach pionową czerwoną linią.

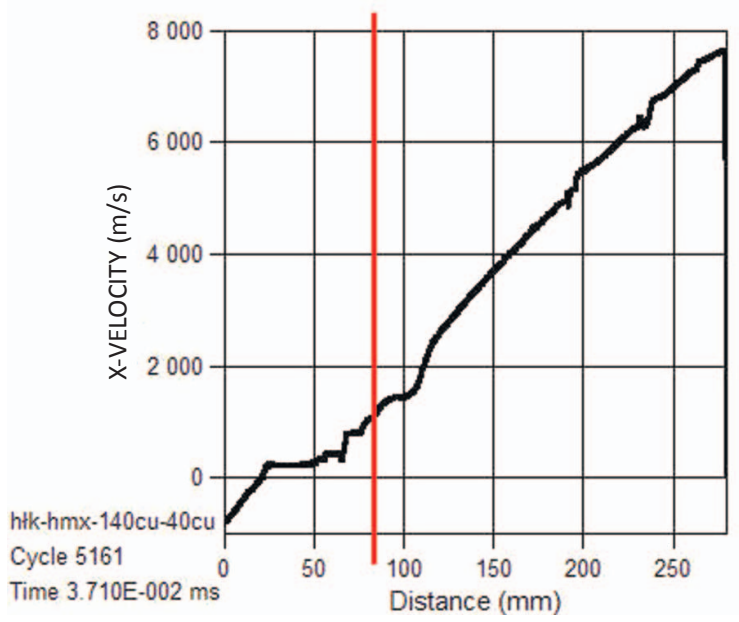

Rys. 7. Rozkład prędkości wzdłuż strumienia kumulacyjnego dla czasu $T=37,10 \mu$ s
MODEL ŁKH45-140-40-Cu-przestona; ładunek kumulacyjny hybrydowy z przesłoną - wkładka kumulacyjna 140Cu2mm + 40Cu

Do kolejnego (II) cyklu analiz numerycznych wybrano konstrukcję małokalibrowego ładunku kumulacyjnego o średnicy wkładki $45 \mathrm{~mm}$ i konstrukcji hybrydowej, tj. o podwójnym kącie wierzchołkowym wkładki: $140^{\circ}$ i 40․ Wkładkę kumulacyjną centralną z miedzi o kącie wierzchołkowym $40^{\circ}$ przyjęto o zmiennej grubości: od $0,5 \mathrm{~mm}$ w części wierzchołkowej do $2 \mathrm{~mm}$ u podstawy. Część zewnętrzna wkładki, także z miedzi, o kącie wierzchołkowym $140^{\circ}$, posiada grubość $2 \mathrm{~mm}$. W ładunku zastosowano dodatkowo przesłonę.

Cechy geometryczne układu hybrydowego ładunku z wkładką o przyjętej konstrukcji i przesłoną, wraz z siatką współrzędnych, przedstawiono na rysunku 8.

Model 2D ładunku jest bardzo zbliżony do przedstawionego poprzednio, natomiast różnica polega na tym, że w ła-

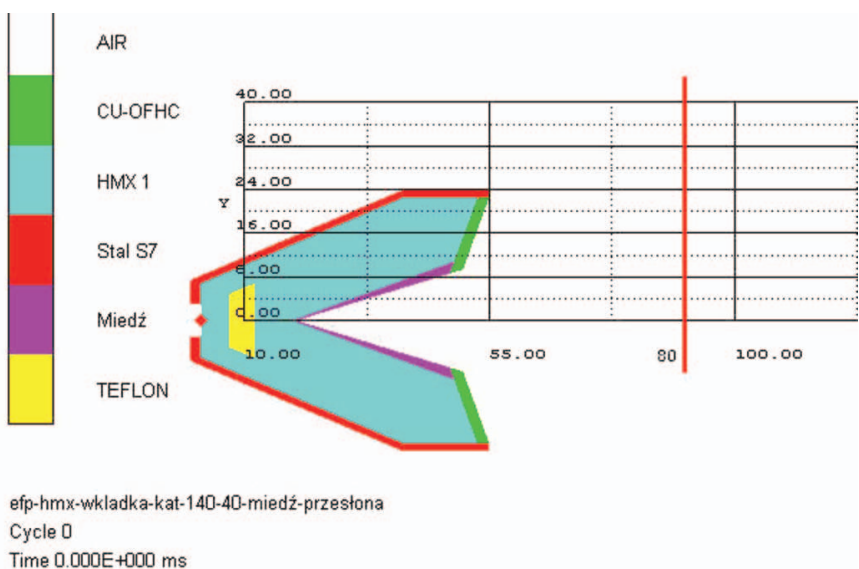

Time 0.000E+000 ms

Rys. 8. MODEL ŁKH45-140-40-Cu-przesłona; ładunek kumulacyjny hybrydowy z przesłoną - wkładka kumulacyjna $140^{\circ} \mathrm{Cu} 2 \mathrm{~mm}+40^{\circ} \mathrm{Cu}$ 

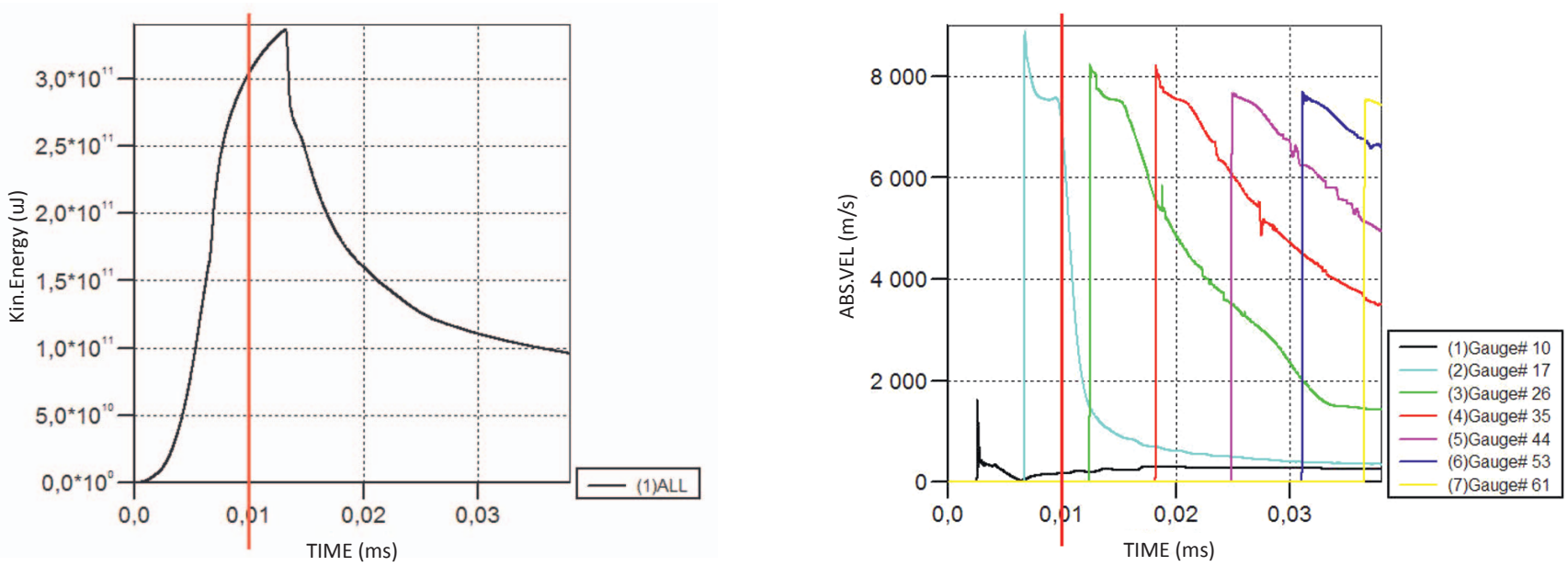

Rys. 9. Przykłady wybranych analiz dla modelu; a) wykresy energii kinetycznej w układzie, b) wykres historii prędkości $A B S$.

$V E L$. $(\mathrm{m} / \mathrm{s})$ dla wybranych punktów kontrolnych odpowiadających położeniom: $S=0$ (pkt 17), $S=1$ (pkt 26), $S=5$ (pkt 61$)$

dunku MW na drodze od miejsca punktowego inicjowania detonacji (punkt $\mathrm{X}=2, \mathrm{Y}=0$, oznaczony kolorem czerwonym) do wierzchołka wkładki kumulacyjnej zastosowano przesłonę wykonaną z materiału obojętnego (teflon). Wobec tego w tym modelu mamy obwodowe inicjowanie detonacji powierzchnią toroidalną. Zasady budowania modelu numerycznego i dane materiałowe przyjęto jak w modelu ŁKH45-140-40-Mg.

W wyniku obliczeń numerycznych podobnych jak dla poprzedniego modelu uzyskano dane energii kinetycznej i prędkości cząstek strugi kumulacyjnej, przedstawione na rysunkach 9a i 9b.

\section{MODEL ŁK45-HIPERKUM-50-Mg-przesłona-} obudowa W; ładunek z efektem hiperkumulacji $z$ przesłoną $w$ obudowie $W$ - wkładka magnezowa $50^{\circ}$

Do kolejnego (III) cyklu analiz numerycznych przyjęto konstrukcję małokalibrowego ładunku kumulacyjnego w obudowie o takim samym kształcie jak w poprzednich przypadkach. Zastosowano wkładkę stożkową ściętą, o kącie wierzchołkowym $50^{\circ}$ i o grubości ścianki 0,5 mm. Wkładkę kumulacyjną stożkową z magnezu w miejscu ścięcia zamyka krążek metalowy o grubości $1 \mathrm{~mm}$.

Cechy geometryczne III układu ładunku z wkładką o przyjętej konstrukcji, z efektem hiperkumulacji, wraz z siatką współrzędnych, przedstawiono na rysunku 10 .

Model 2D ładunku o symetrii osiowej umieszczony jest w przestrzeni o długości $130 \mathrm{~mm}$ (współrzędna X od -20 mm do $110 \mathrm{~mm}$ ) i szerokości $80 \mathrm{~mm}$ (współrzędna promieniowa $Y$ od $0 \mathrm{~mm}$ do $40 \mathrm{~mm}$ ). Współrzędne odległości $X=55 \mathrm{~mm}$, $100 \mathrm{~mm}$ odpowiadają dystansom od podstawy wkładki kumulacyjnej mierzonym jej krotnością w kalibrach $S=0,1$. W ładunku MW na drodze od miejsca punktowego inicjowania detonacji (punkt $\mathrm{X}=2, \mathrm{Y}=0$, oznaczony kolorem czerwonym) do wierzchołka wkładki kumulacyjnej zastosowano przesłonę wykonaną z materiału obojętnego (teflon). Wobec tego za przesłoną występuje w tym modelu obwodowe inicjowanie detonacji powierzchnią toroidalną.

Na rysunku 11 przedstawiono obraz konturu prędkości ABS.VEL $(\mathrm{m} / \mathrm{s})$ i wykres rozkładu prędkości wzdłuż strumienia dla położenia czoła strumienia w odległości $S=1$. Obrazuje on zmianę maksymalnej prędkości elementów czoła strumienia Vo. Prędkość czoła strumienia powstałego z wkładki magnezowej - na dystansach od $S=0$ do $S=1$ mieści się w granicach 12,4 $\div 11,6 \mathrm{~km} / \mathrm{s}$. Prędkość zmniejsza się wraz $\mathrm{z}$ odległością od podstawy ładunku.

Na rysunku 12 przedstawiono wybrane inne przykłady $\mathrm{z}$ analizy danych dla modelu, które program gromadzi w procesie całego cyklu symulacji.

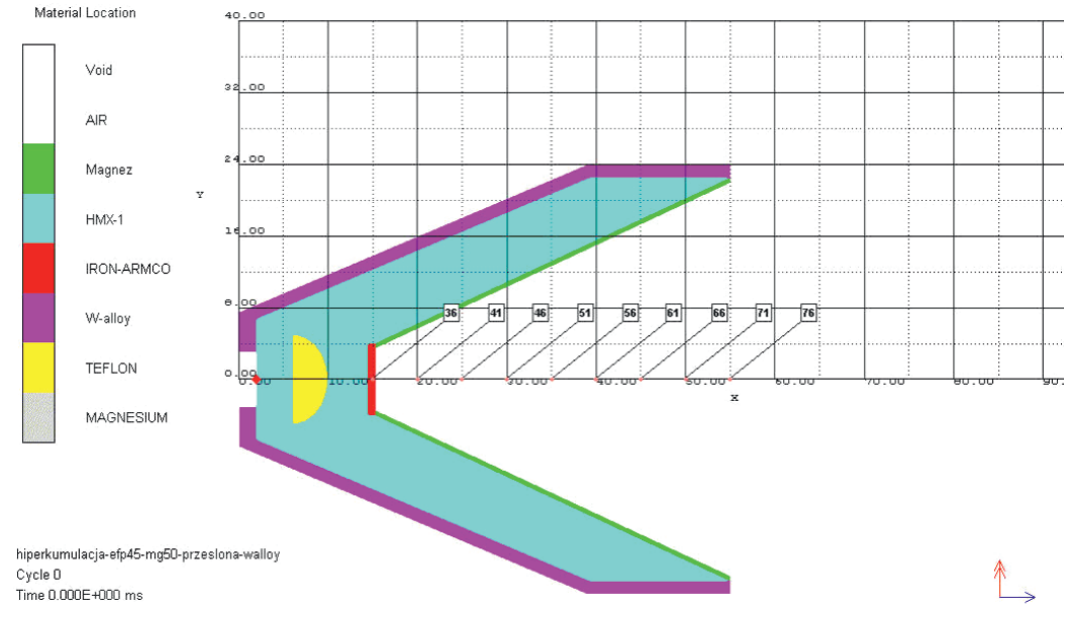

Rys. 10. MODEL ŁK45-HIPERKUM-50-mg-przesłona-obudowa W; ładunek kumulacyjny z efektem hiperkumulacji z przesłoną w obudowie $\mathrm{W}$ - wkładka kumulacyjna $50^{\circ} \mathrm{Mg}$, grubość $0,5 \mathrm{~mm}$ 

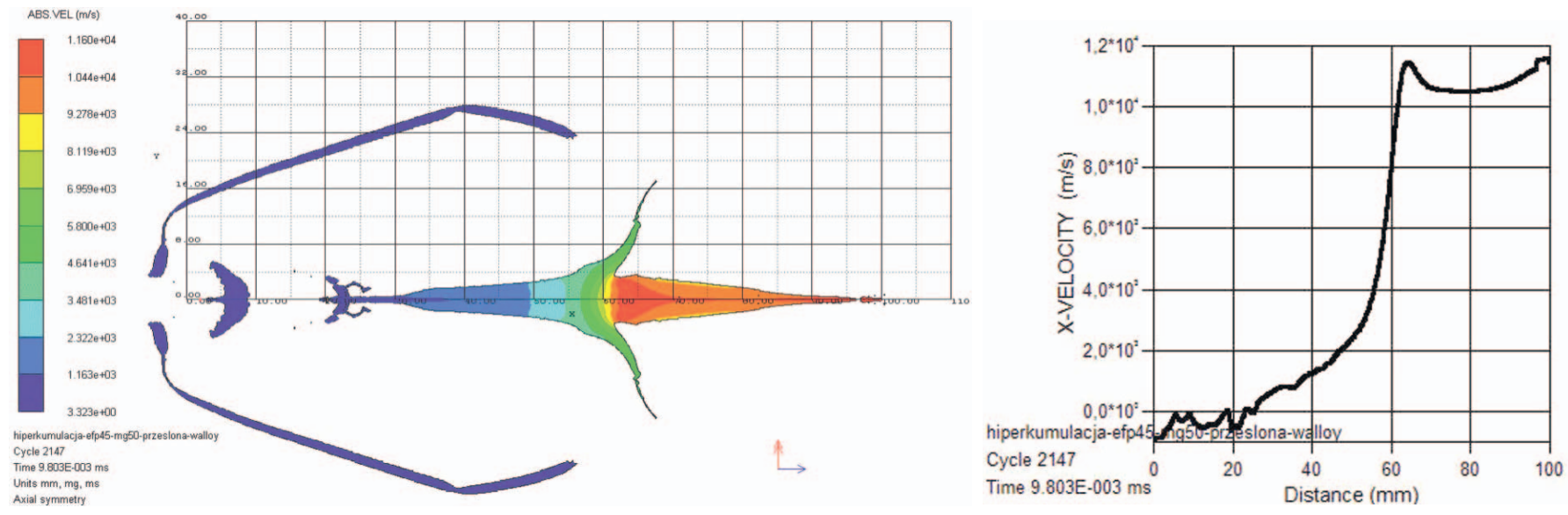

$S=1$

Rys. 11. Obrazy konturów prędkości i rozkład prędkości na długości dla położenia czoła strumienia: $S=1\left(V_{\text {omax }}=11600 \mathrm{~m} / \mathrm{s}\right)$
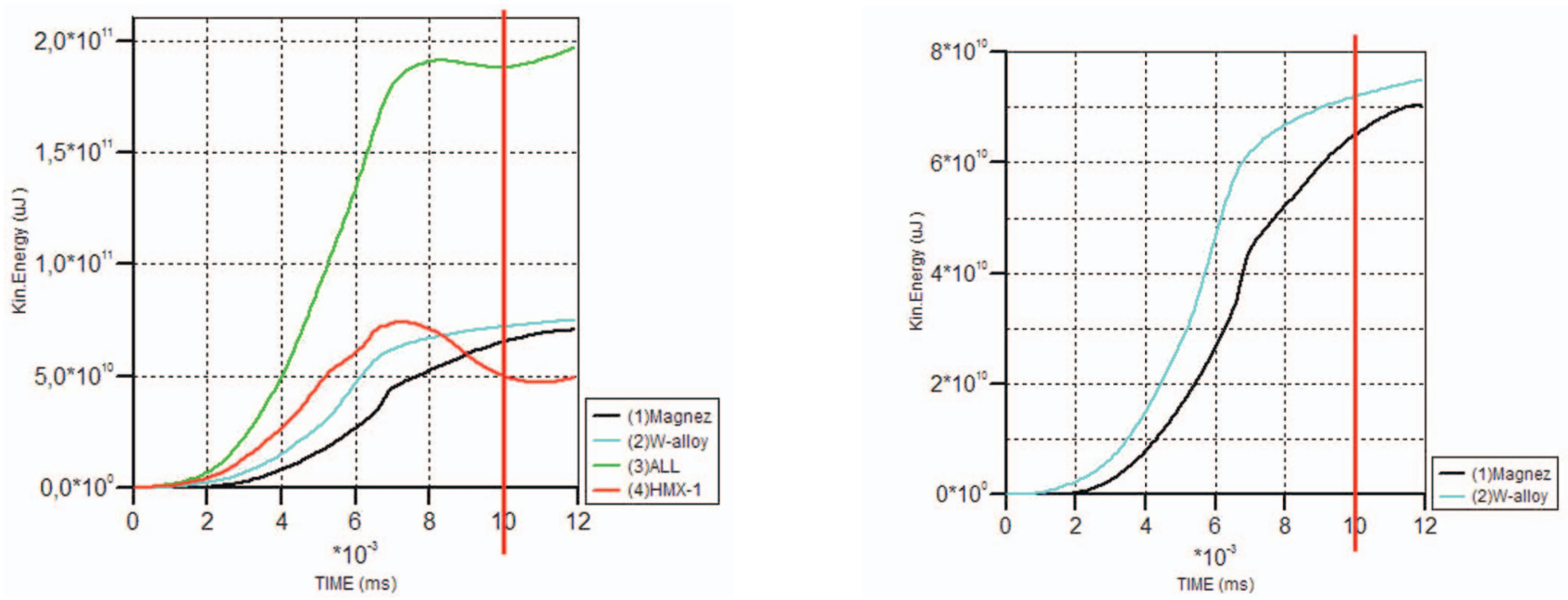

Rys. 12. Przykłady wybranych analiz dla modelu: wykresy energii kinetycznej poszczególnych składników w układzie

Początek narastania energii kinetycznej elementów wkładki kumulacyjnej jest związany z dotarciem do niej fali detonacyjnej. Ustalenie się energii kinetycznej strumienia (magnez) następuje po czasie około $12 \mu \mathrm{s}$, licząc od początku detonacji. Wartość energii kinetycznej przekazanej do strumienia z magnezu wynosi około $70 \mathrm{~kJ}$.

\section{Ocena energii kinetycznej dla celów pobudzania zapłonu paliwa}

Wielkości energii kinetycznych generowanych poprzez poszczególne ładunki modelowe i obliczonych metodami numerycznymi dla tych modeli zestawiono z wynikami prac $[4,6,7]$, w których drogą kolejnych osłabień energii strugi kumulacyjnej poszukiwano najmniejszej energii pobudzającej jeszcze zapłon paliwa wysokoenergetycznego.

Wielkość tej energii (dla paliwa wysokoenergetycznego typu „Szmaragd”) została wówczas określona jako 1/6 całkowitej energii strugi kumulacyjnej w punkcie kontaktu z paliwem wysokoenergetycznym (pobudzanych było 6 kolejnych warstw paliwa, gdy struga przebijała 6 kolejnych zespołów płytki stalowej + płytki paliwa, siódma z kolei nie była już pobudzana).

Wielkości szacunkowe energii kinetycznej dla modeli trzech badanych typów ładunków, określone dla odległości $25 \mathrm{~mm}$ od czoła wkładki kumulacyjnej (czyli na modelach: $55+25=80 \mathrm{~mm}$ ), tj. odległości, w której znajdzie się środek grubości płaszczowego paliwa stałego na korpusie perforatora, pokazano jako ułamki w tablicy 2 .

Tablica 2. Porównanie wartości energii kinetycznych

\begin{tabular}{|c|c|c|}
\hline $\begin{array}{c}\mathrm{Nr} \\
\text { modelu }\end{array}$ & $\begin{array}{c}\text { Energia kinetyczna na } \\
\text { dystansie } 80 \text { mm (na czasie } \\
\text { 0,01 ms), szacunkowo: } \\
\text { ułamek pełnej energii } \\
\text { pobudzania }\end{array}$ & $\begin{array}{c}\text { Minimalna energia } \\
\text { pobudzania oszacowana } \\
\text { na podstawie strzelań } \\
\text { poligonowych }\end{array}$ \\
\hline 1 & $9 / 10$ & \multirow{2}{*}{$1 / 6$ energii całkowitej } \\
\hline 2 & $9 / 10$ & \\
\hline 3 & $9 / 10$ & \\
\hline
\end{tabular}




\section{Podsumowanie i wnioski}

W pracy przedstawiono proces kumulacji, rozpatrując zagadnienie dla przypadków analiz układów kumulacyjnych o trzech różnych typach wkładek (hybrydowa, hybrydowa z przesłoną, hiperkumulacyjna).

Wykazano, że energia strugi kumulacyjnej w oszacowanej odległości, w której w układzie znajdzie się płaszcz paliwa wysokoenergetycznego perfogeneratora, jest w każdym przypadku wystarczająca do spowodowania zapłonu paliwa wysokoenergetycznego.

Wykazano, że zastosowanie dodatkowych przesłon (płytek) wpływa na prędkości tworzących się strumieni. Umiejscowienie wkładek w postaci płaskich krążków na ściętych stożkach kumulacyjnych powoduje zmianę położenia tworzenia się punktów kolizji w związku z pozaosiową interakcją produktów detonacji. W punktach tych powstają dodatkowe strumienie, które w wyniku zderzenia się ze sobą ge- nerują właściwy strumień. Zasadniczy strumień przekracza w początkowej fazie prędkość $18 \mathrm{~km} / \mathrm{s}$, a następnie stabilizuje się i osiąga prędkości $12 \div 15 \mathrm{~km} / \mathrm{s}$ (w zależności od materiału wkładki).

Wraz ze zwiększeniem się prędkości strumieni obserwuje się wzrost energii, co bezpośrednio przekłada się na skuteczność perforacji tych ładunków i możliwość pobudzania modyfikowanych paliw wysokoenergetycznych, czego potwierdzenia poszukiwano w tej pracy.

W analizowanych przypadkach, w których wkładki były kombinowane (hybrydowe), obserwuje się powstawanie zarówno strumieni klasycznych, jak i odwrotnych typu EFP (pocisk formowany wybuchowo).

Praca stanowi przyczynek do propozycji nowych rozwiązań konstrukcyjnych, badań i prac aplikacyjnych dla zastosowań praktycznych (np. w ładunkach do perforacji otworowej).

Prosimy cytować jako: Nafta-Gaz 2016, nr 10, s. 841-850, DOI: 10.18668/NG.2016.10.09

Artykuł nadesłano do Redakcji 10.11.2015 r. Zatwierdzono do druku 4.07.2016 r.

\section{Literatura}

[1] Frodyma A.: Intensywne udostępnianie złóż węglowodorów technika perforacyjna. Czesść I - Uszkodzenie perforacyjne strefy przyotworowej. Nafta-Gaz 2011, nr 7, s. 467-473.

[2] Frodyma A.: Intensywne udostępnianie złóż węglowodorów technika perforacyjna. Część II - Perforacja przy ekstremalnym nadciśnieniu. Nafta-Gaz 2011, nr 8, s. 552-561.

[3] Frodyma A.: Zasady i podstawy projektowania zabiegów stymulacji otworów wiertniczych z zastosowaniem paliw stałych. Nafta-Gaz 2012, nr 9, s. 590-601.

[4] Habera Ł.: Badania zapłonu propelantów na stacjonarnym silniku laboratoryjnym. Nafta Gaz 2014, nr 11, s. 778-783.

[5] Habera Ł., Frodyma A., Godzik A.: Symulacja numeryczna procesu spalania paliwa o zróżnicowanych charakterystykach geometrycznych. Dokumentacja Instytutu Nafty i Gazu - PIB 2011, nr 16/ST.

[6] Habera Ł., Frodyma A., Koślik P., Wilk Z.: Nowoczesne urzqdzenia perforująco-szczelinujace - koncepcja i badania poligonowe. Nafta-Gaz 2014, nr 5, s. 301-306.

[7] Habera Ł., Frodyma A., Wilk Z., Koślik P.: Badania poligonowe zapłonu paliw prochowych stosowanych $w$ perfogeneratorach. Nafta-Gaz 2012, nr 3, s. 180-183.

[8] Kupidura Z., Wilk Z., Zygmunt B.: Zastosowanie wysokoenergetycznych kompozycji materiałów wybuchowych z teflonem (PTFE) $w$ dziedzinie kumulacji wybuchowej.
Problemy Techniki Uzbrojenia i Radiolokacji 1998, nr 65, s. $61-69$

[9] Minin I. V., Minin O. V.: Physics of hypercumulation: jet formation in shaped charge and ablatively-driven implosion of hollow cones. International Letters of Chemistry, Physics and Astronomy 2014, vol. 22, s. 76-86.

[10] Minin V. F., Minin I. V., Minin O. V.: Physics of hypercumulation and combined shaped charges. Proc. $11^{\text {th }}$ International conference on actual problems of electronic instrument engineering (APEIE), NSTU, Novosibirsk 2012, vol. 1, s. 34-52.

[11] Nowak H., Smoleński D.: Ładunki kumulacyjne w wojsku, górnictwie i przemyśle. Warszawa, Wydawnictwo MON, 1974.

[12] Wilk Z.: Opracowanie konstrukcji i technologii ładunków kumulacyjnych do efektywnej perforacji w odwiertach geologicznych. Rozprawa doktorska. WAT, Wydział Mechatroniki, Warszawa 2008.

\section{Patenty}

[13] Minin V. F., Minin I. V., Minin O. V.: Patent of Russia Nr 2012103156/11 (004630) 2012.

[14] Minin V. F., Minin I. V., Minin O. V.: Patent of Russia Nr 2012107107/11 (010783) 2012.

[15] Minin V. F., Minin I. V., Minin O. V.: Patent of the Russian Federation Nr 2412338.

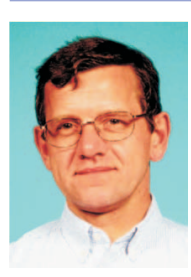

Mgr inż. Antoni FRODYMA

Główny specjalista inżynieryjno-techniczny;

kierownik Zakładu Techniki Strzelniczej.

Instytut Nafty i Gazu - Państwowy Instytut Badawczy

ul. Lubicz 25 A

31-503 Kraków

E-mail: antoni.frodyma@inig.pl

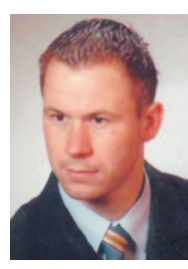

Mgr inż. Piotr KOŚLIK

Specjalista badawczo-techniczny w Instytucie

Przemysłu Organicznego w Warszawie Oddział

w Krupskim Młynie.

ul. Zawadzkiego 1

42-693 Krupski Młyn

E-mail:piotr.koslik@ipo.waw.pl 